\title{
長寿命溶射リップの開発*
}

株式会社野村鍍金 技術部 ○清水 亮, 藤田 得生

\section{Development of Longlife Suction Box Lip}

Ryo Shimizu and Norio Fujita

Nomura Plating Co.. LTD

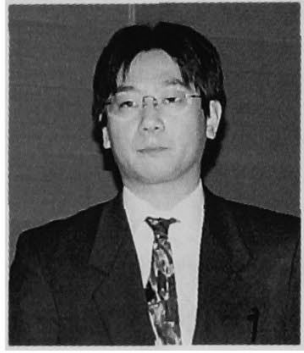

清水 亮

A felt suction box is installed in the press section on a paper machine. It is useful for removing white water and shower water for felt cleaning by effect of vacuum. Our company developed of sprayed suction box lip that is a round type at 1997. We started the development of longlife sprayed suction box lip that is a flat face type for longlife, lower price and lighter. Suction box lip combined a resin body and spraying material on stainress steel. Result of fundamental experiment, we chose special phenolic resin and FRP from resin and epoxy adhesive from adhesive. We examined WC- $\mathrm{NiCr}$ spraying. $\mathrm{Cr}_{2} \mathrm{O}_{3}$ spraying. $\mathrm{Al}_{2} \mathrm{O}_{3}-\mathrm{TiO}_{2}$ spraying. $\mathrm{ZrO}_{2}$ spraying. $\mathrm{Ni}-\mathrm{P}$ plating dispersing $\mathrm{SiC}, \mathrm{Ni}-\mathrm{W}$ plating. $\mathrm{Cr}$ plating and sintered $\mathrm{Al}_{2} \mathrm{O}_{3}$ by referring the result of taber abration test. After the wear resistance examination, we understood the followings by evaluate the lesswear, damage of felt, scratch on lip surface. Regarding for wear. WC $-\mathrm{NiCr}$ spraying and $\mathrm{Al}, \mathrm{O}_{1}-\mathrm{TiO}_{2}$ spraying are superior than other samples. $\mathrm{Al}_{2} \mathrm{O}_{3}-\mathrm{TiO}_{2}$ spraying is the most suitable about wear resistance and spraying thickness. On the other hand $\mathrm{Cr}_{2} \mathrm{O}_{3}$ spraying is the most suitable about effect of less felt damage.

分類： $M_{6}$ ブレス, $M_{1}$ 抄紙・抄紙機一般

\section{1.はじめに}

フェルトサクションボックス (別名：ユールボック ス）は抄紙機のプレスパートに設置され，真空を作用 させる事で湿紙から脱水されたフェルト中の白水及び フェルトをクリーニングするシャワー水除去等の役目 がある: そしてパキュームの吸引力により, フェルト の表面を常に清浄に保つ機能をもっている。フェルト サクションボックスに装着したリップ表面はフェルト による擦れと白水に含まれる炭酸カルシウム等の研磨

*平成 14 年度年次大会講演（講演 No. C 20)
作用によって摩耗し，イレギュラーな表面状態になる とバキュームが立たなくなり、リップとして機能しな くなる。

原則的に見れば，昭和 60 年頃までのマシーンはモ ネル, 17-7 PH, 17-4 PH の研磨棒を利用していたが, 抄紙が速くなるにつれ、サクションリップの構成材料 が長寿命化を目的として，それまでの金属材料からセ ラミック製に変化して現在に至っている。また, 形状 的にも真空幅の変更やリップ清掃の観点からリップ交 换が容易である T瑇付の角型リップに推移した。し かし, セラミックインゴット製のリップは, コストが 高いとか, フェルトの椇傷や脱インク原料を採用して 


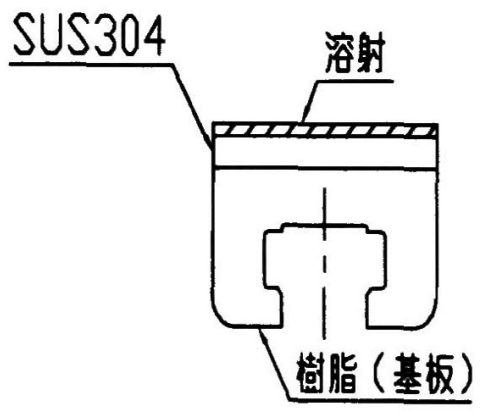

図 1 角型リップ

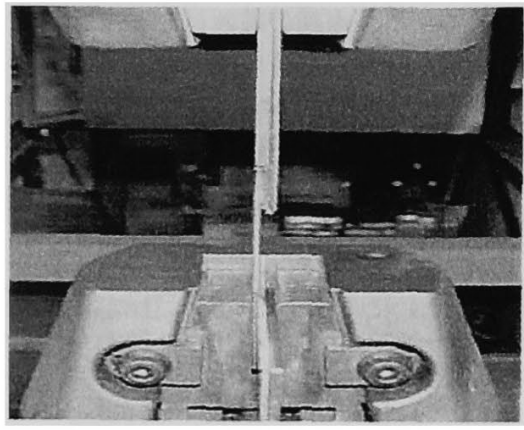

図 2 引張試験概要
以来ピッチが付着しやすくなって污れる等の問題もあ るようである。当社では’ 97 年に溶射丸形リップを 開発したが, コスト低下, 軽量化, 取り扱いの容易性 をねらって図1に示すように，表面処理を施したステ ンレスの板と樹脂の基板とを接着した角型リップの開 発を再スタートした。

\section{2. リップ基板}

サクションリップの基板（図 1 参照）は軽量化を目 的として樹脂材料を採用した。この際，樹脂材料につ いては以下に示す物性及び製作可能条件等について検 討した。

〔樹脂材料に於ける選定項目〕

1 吸水率が低い

(2) 熱膨張俰数が $1.7 \times 10^{-5}$ 程度である

(3) 酎熱温度が高い

(4) 長尺の製品が製作可能である

(5) 耐薬品性がある

(6) 低コストである

数種類の候補材質の中で，上記条件をほほ満たすも のとして特殊フェノール樹脂及び FRP を選定した。

\section{3. 接着試験}

開発をスタートした角型リップは図 1 のごとく表面
処理を施したステンレスの板と樹脂製基板を接着する 構造としている。従って樹脂材料とステンレス材の接 着強度が問題となるので, リッフ接着に使用する接着 郕の検討を行なった。この際，接着剤については下記 項目に関して検討した。

〔接着剤に関する検討項目〕

(1) 基板の熱変形をさけるため非熱硬化型, 非加圧 型のものであること。

2 製紙部門では大量の水が使用されるため酎水性 のあること。

(3) フェルト洗浄には化学薬品が使用されるため耐 薬品性のあること。

(4) ステンレス材と樹脂材料とが一定強度の接着力 で接着できること。

\section{1 実験方法}

万能試験機を用いて引張試験を行ない，接着強度を 測定した (試験要領は図 2 参照)。引張試験は 1 つの 組み合わせに対して 3 回ずつ行ない, その平均値を接 着強度とした。この時の接着材料及び接着条件を表 1 にまた，テストピース寸法を図 $3 に$ 示す。

\section{2 実験 結果}

接着試験の結果（図 4)により以下のことが分った。 (1) 3 種類の接着片の中ではエポキシ系接着郕の接 着強度が一番高い。

表 1 接着材料及び接着条件

\begin{tabular}{c|l}
\hline 金属材料 & SUS 304 \\
\hline 樹脂材 料 & 特殊フェノール樹脂, FRP \\
\hline 接 着 郕 & 合成コム系, 特殊合成樹脂系, エポキシ系 \\
\hline 接 着 面 積 & $4 \mathrm{~cm}^{2}$ \\
\hline 前 処 理 & SUS 304, 樹脂材料共に受入れ材のままアセトンで脱脂 \\
\hline 接着後放置時間 & $24 \mathrm{~h}$ \\
\hline
\end{tabular}


2、エポキシ系接着剤の破断は急激に起こるが，合 成ゴム系及び特殊合成樹脂系接着剤は引張りはじ めると同時に接着剂が延び，引張曲線には破断点 が現れなかった。

(3) どの組み合わせにおいても樹脂材料と接着剂の

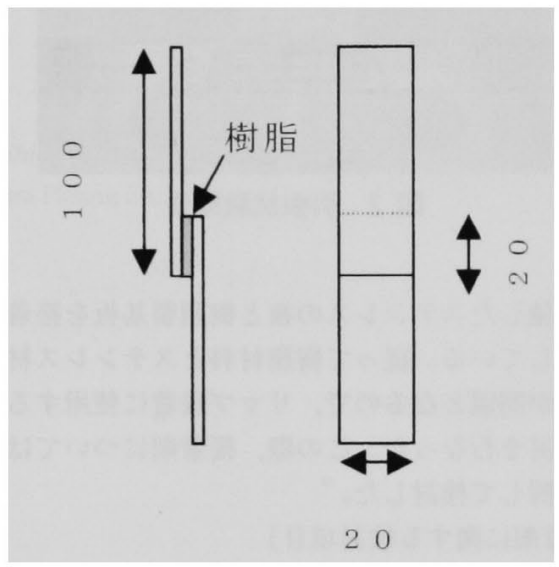

図 3 テストピース寸法

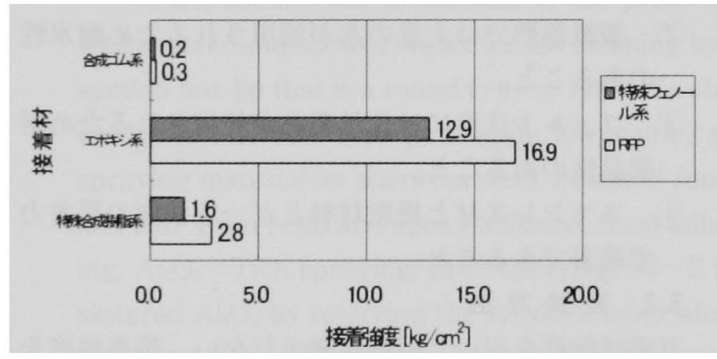

図 4 接着強度試験結果
界面で破断していた。

なお, 接着強度は真空度： $500 \mathrm{mmHg}$, 縻擦係数 : 1 と仮定して単位面皘当りにかかるせん断強度と安全 率とを考虑し, $7 \mathrm{~kg} / \mathrm{cm}^{2}$ 以上を目標とした。上記結 果から本述リップの接着には接着強度が $7 \mathrm{~kg} / \mathrm{cm}^{2}$ 以 上確保し得るエポキシ系接着剤を用いることとした。

\section{4. 皮膜材料選定のための予備試験}

リップ皮膜材料選定にあたっての予備試験としてテ 一バー摩耗試験（アブレッシブ摩耗試験法）により, 材料摩耗特性を調べることによって後に行なう擬似り ップ摩耗試験皮膜の選別を行なった。

\section{1 試 験 方 法}

テーバー摩耗試験機により, 荷重 $1 \mathrm{~kg}$ のにに摩耗 輪 H-10（材質：SiC）を使用して 1,000 回転每の重量 減少量を測定し,これを摩耗体積に換算して摩耗量と した。

\section{2 予備摩耗試験の結果}

テーバー摩耗試験の結果（図 5) からクロムめっき, アルミナ焼結体 (比較材料), タングステンカーバイ ド溶射等が耐摩耗特性に優れている事が分った。一方, 現用リップにおいては摩耗に加えて相手材のフェルト の損傷も併せて検討する必要があるので, この予備試 験で選定した 8 種類の候補材について擬似リップ摩耗 試験を行なうこととした。

\section{5. 擬似リップ摩耗試験}

リップに適用した皮膜材料とフェルトとを実際に接 触させて摩耗させる擬似リップ摩耗試験を長期問にわ

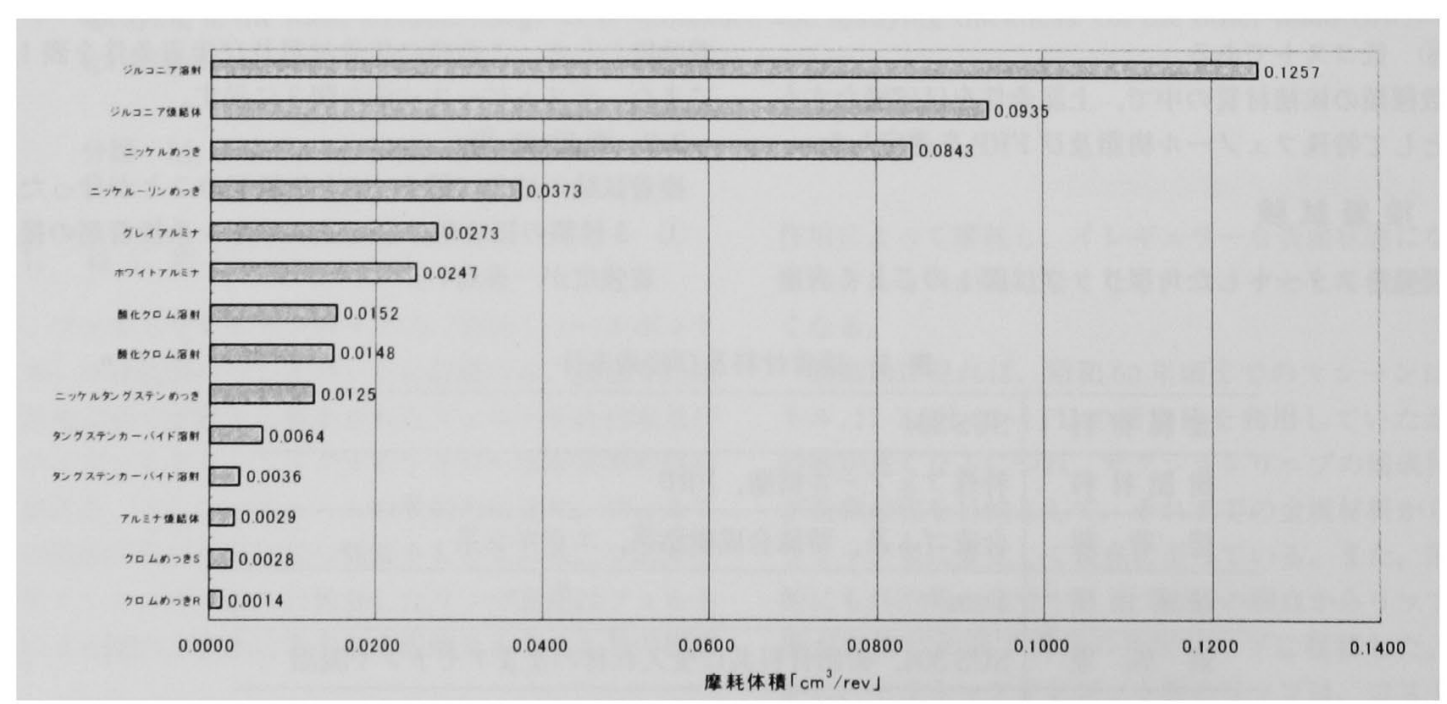

図 5 テーパー摩耗試験結果 

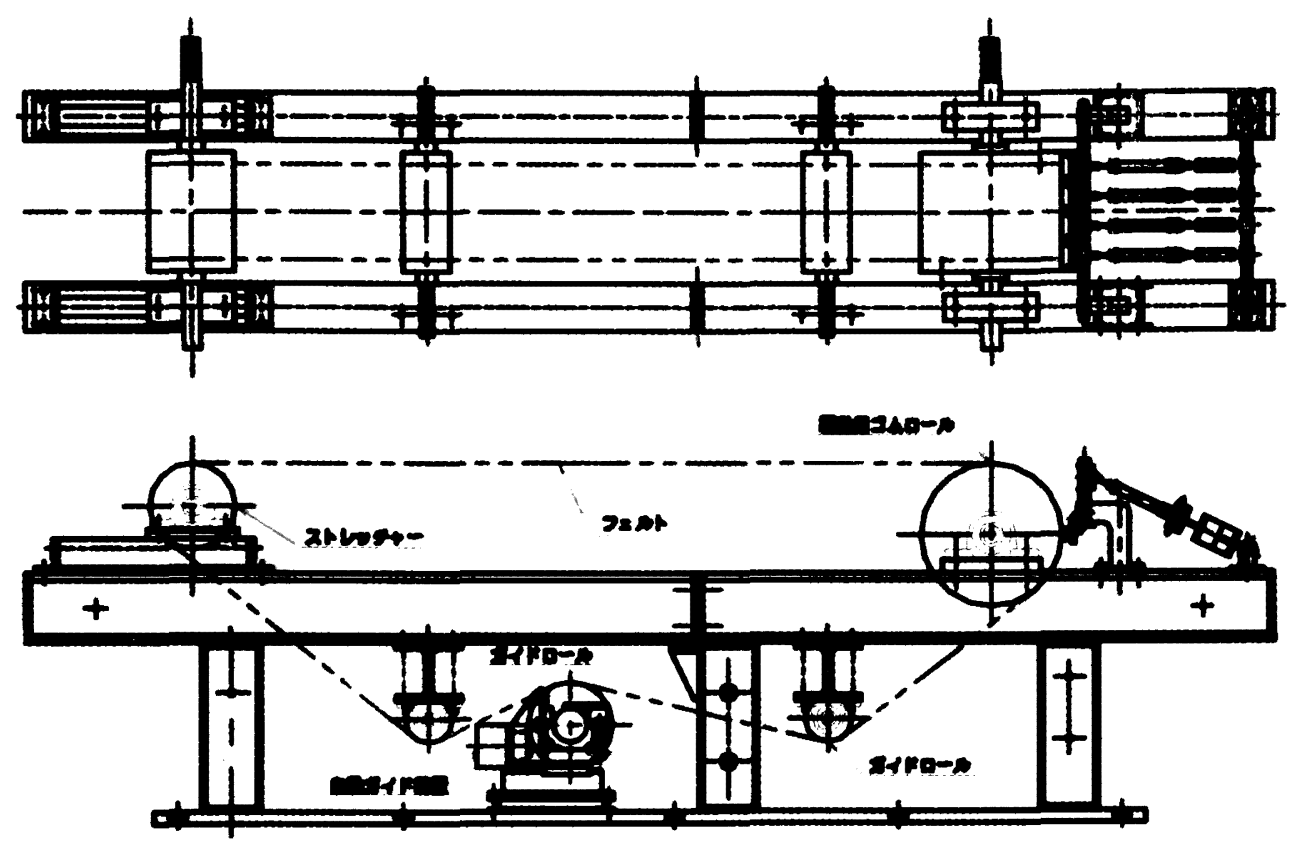

図 6 擬似リップ摩耗試験機

たって実施しリップとフェルトに対してどのような 現象が起こるか, そしてどの程度皮膜材料が摩耗する のかを確認した。なお，この試験に当たっては当社現 有の万能摩耗試験機を目的に合致するように改造して 試験に供した。改造した擬似摩耗試験機の構成を図 6 に示す。

\section{1 擬似リップ摩耗試験の概要}

摩耗試験要部の説明を図7に示す。図7ではリッフ をフェルトにばね力で押し付け，水シャワーをかけな がらフェルトを走行させることによって強制的に摩耗 させるようにしている。なお, 実験に用いたフェルト

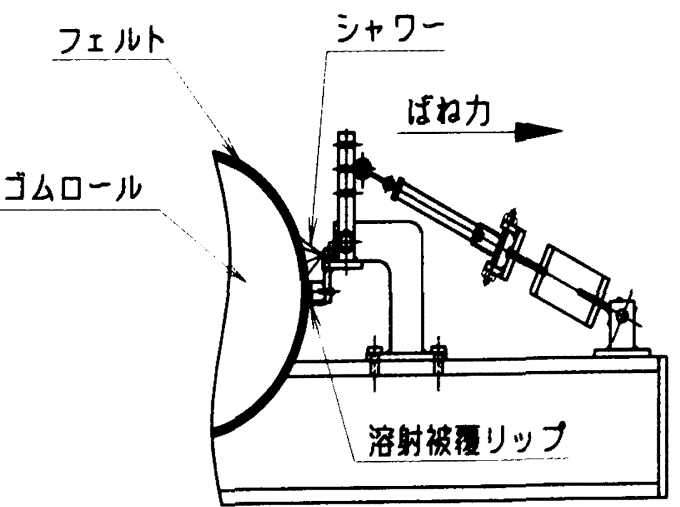

図 7 摩耗試験要部
表 2 フェルト仕様

\begin{tabular}{c|c}
\hline 目付け & $1,200 \mathrm{~g} / \mathrm{m}^{2}$ \\
\hline 材質 & ナイロン $100 \%$ \\
\hline 切断強度 $(\mathrm{kgf} / \mathrm{cm})$ & 70.1 \\
\hline 伸 度 $(\%)$ & 27.6 \\
\hline 通気度 $\left(\mathrm{cc} \mathrm{cm}^{2} \mathrm{~S}\right)$ & 50 前後 \\
\hline
\end{tabular}

表 3 摩耗試験機運転条件

\begin{tabular}{|c|c|c|}
\hline 運 & 転 速 度 & $800 \mathrm{~m} / \mathrm{min}$ \\
\hline リ & ップ圧力 & $1.88 \mathrm{~kg} / \mathrm{cm}$ \\
\hline 水 & 循 環 量 & $18 l / \mathrm{min}$ \\
\hline
\end{tabular}

*実機操業の真空度が $500 \mathrm{mmHg}$ と仮定

するとリップ压力は実機操業の 2 倍で ある。

\begin{tabular}{lllll|}
$(1)$ & $(4)$ & $(7)$ & (10) & (13) \\
$(2)$ & $(5)$ & $(8)$ & (11) & (14) \\
(3) & (6) & (9) & (12) & (15)
\end{tabular}

図 8 厚み測定位㯰 
表 4 供試リップ適用皮膜の種類

\begin{tabular}{|c|c|}
\hline 溶射 被膜 & $\begin{array}{l}\text { タングステンカーバイド溶射, 酸化クロム溶射, グレーアルミナ溶射, } \\
\text { ジルコニア溶射 }\end{array}$ \\
\hline めっき被膜 & $\mathrm{SiC}$ 分散 $\mathrm{Ni}-\mathrm{P}$ めっき, $\mathrm{Ni}-\mathrm{W}$ めっき, $\mathrm{Cr}$ めっき \\
\hline 焼 結 材 & $\begin{array}{l}\text { アルミナ焼結材 (厚さ } 5 \mathrm{~mm} \text { の焼結材をエポキシ系接着郕で SUS } 304 \\
\text { に接着)/現用比較材料 }\end{array}$ \\
\hline
\end{tabular}
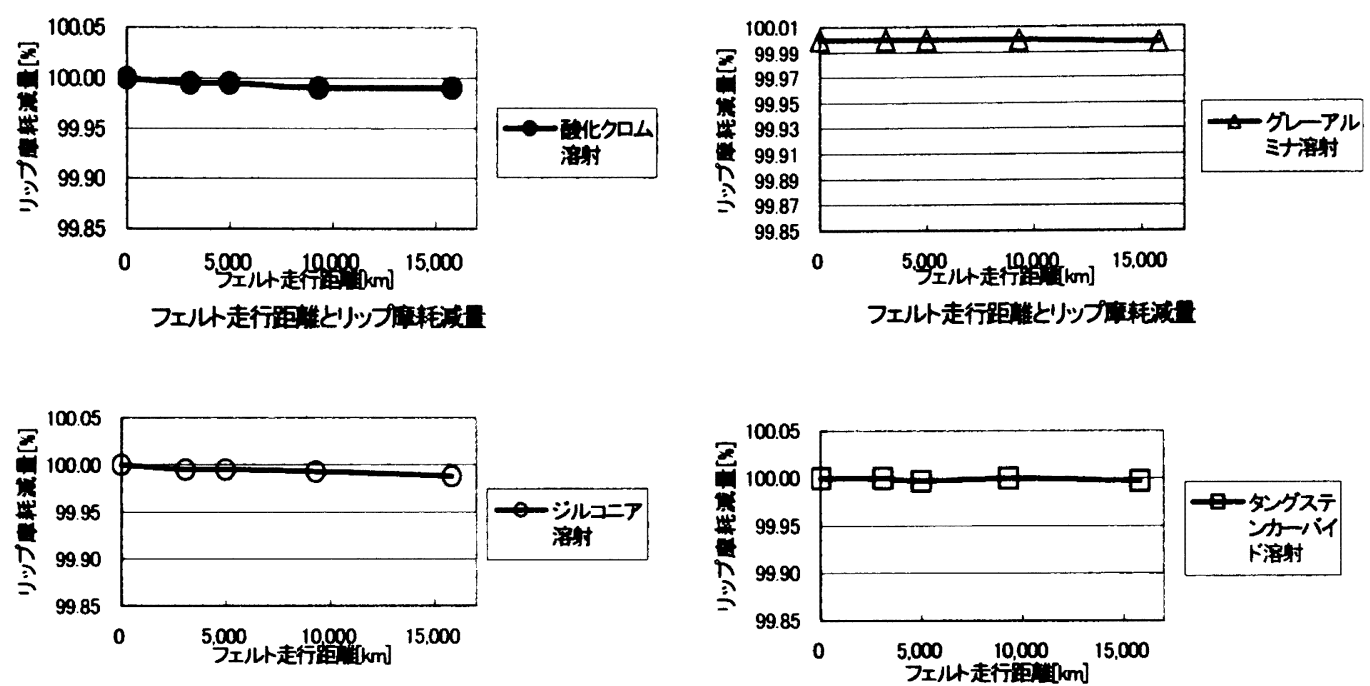

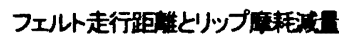
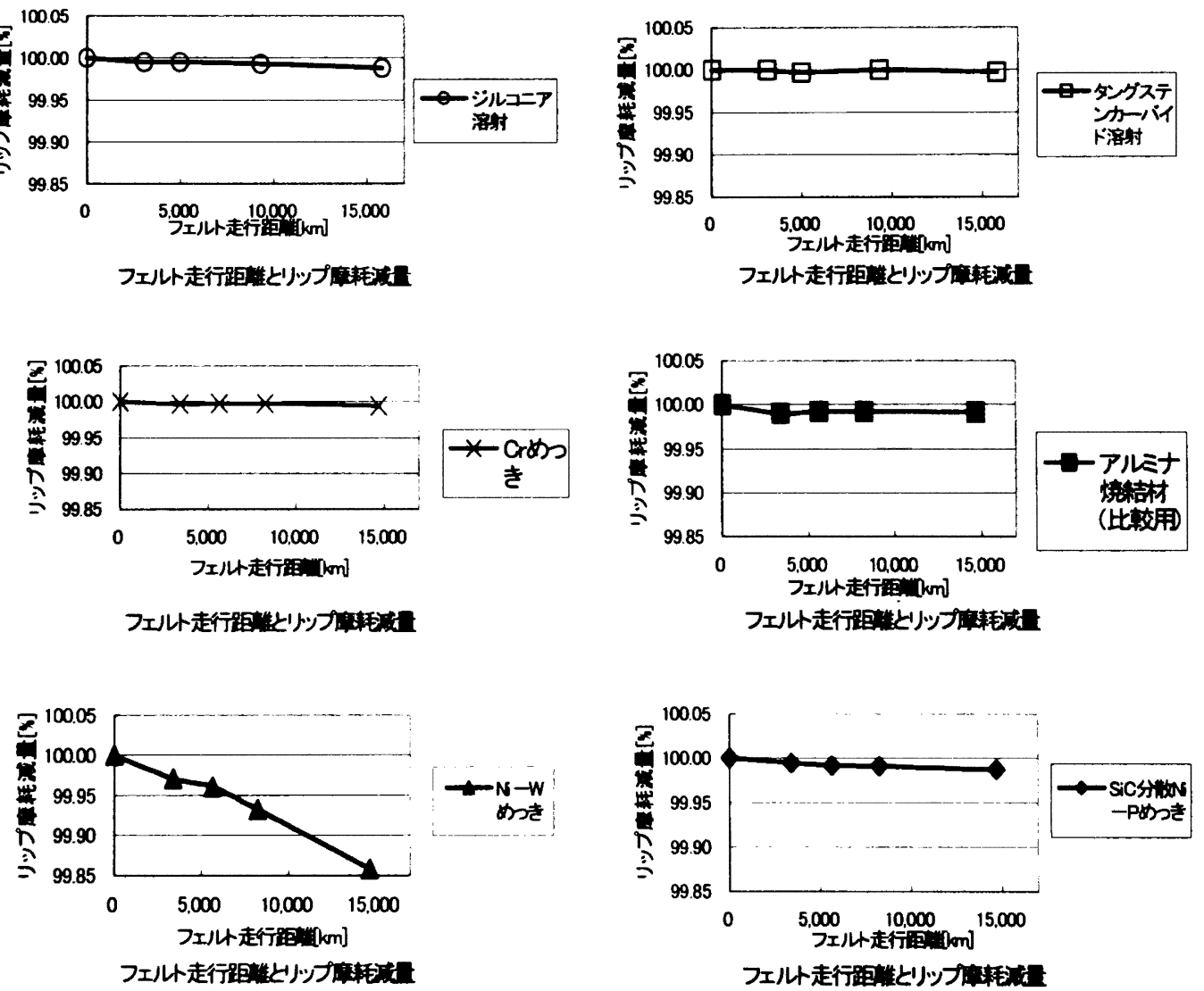

図 9 フェルト走行距離と各種被澓材料摩耗隇量

の仕様は表 2 にまた，実験条件を表 3 に示す。さらに 当該試験に供した各種皮膜の表面仕様については表 4 に示した。この試験では一定走行距離ごとに供試リッ
プの残存厚みの測定や外観写真撮影を行なった。測定 要領は以下の通りである。 

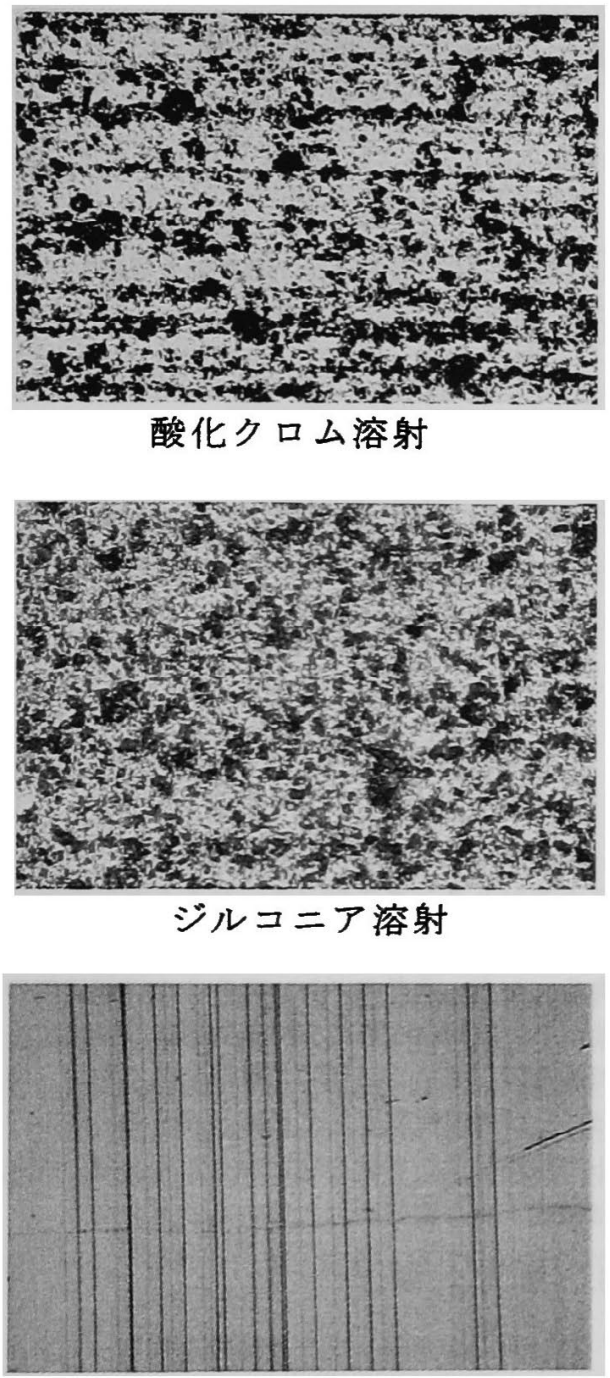

Cr めっき

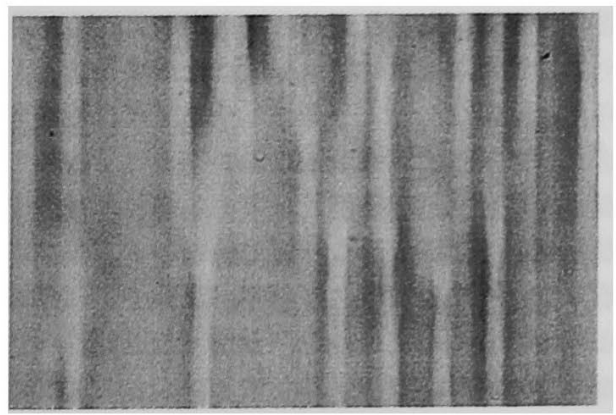

$\mathrm{Ni}-\mathrm{W}$ めき

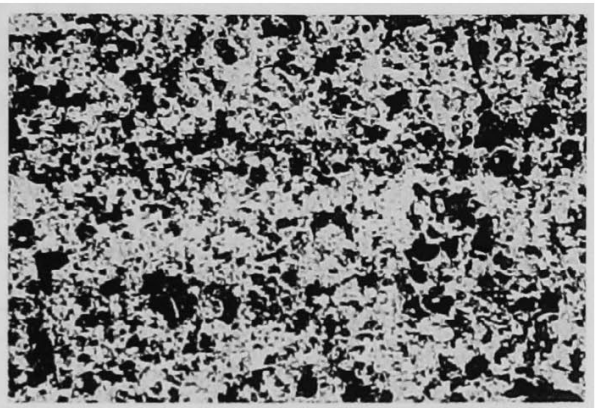

グレーアルミナ溶射

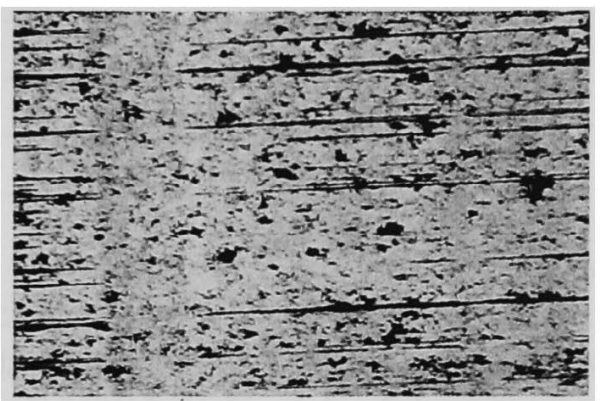

タングステンカーバイド溶射

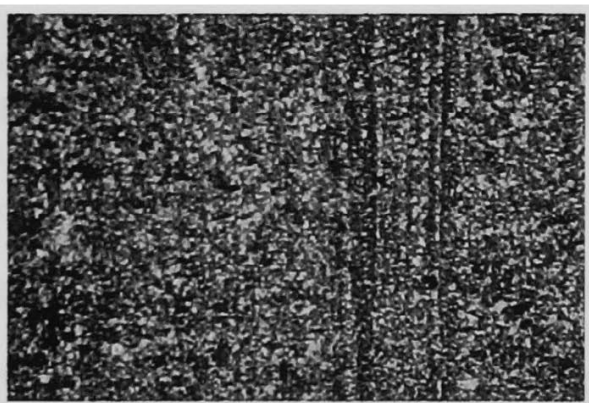

アルミナ焼結材（比較用）

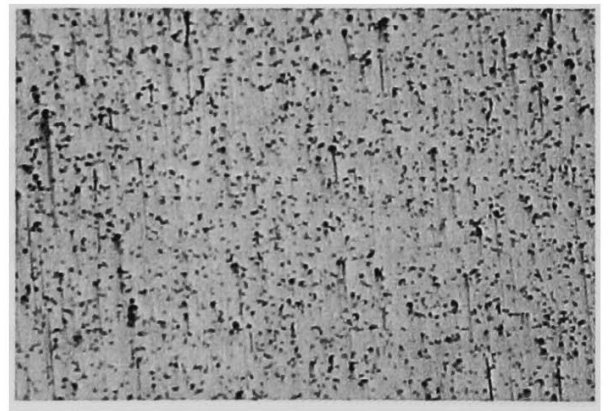

$\mathrm{SiC}$ 分散 $\mathrm{Ni}-\mathrm{P}$ めっき

図 10 摩耗試験後の各種被徣材料の表面ミク口写真 
表 5 各皮膜の特性

\begin{tabular}{|c|c|c|c|c|}
\hline 皮膜 種 類 & $\begin{array}{c}\text { 耐摩 } \\
\text { 耗性 }\end{array}$ & $\begin{array}{c}\text { フェルト損傷 } \\
\text { への影響 }\end{array}$ & $\begin{array}{l}\text { 局 部 } \\
\text { 表面傷 }\end{array}$ & $\begin{array}{l}\text { 総合 } \\
\text { 評価 }\end{array}$ \\
\hline ジルコニア溶射 & 6 & 小 & 3 & 4 \\
\hline グレーアルミナ溶射 & 1 & 中 & 3 & 1 \\
\hline 酸化クロム溶射 & 5 & 小 & 3 & 3 \\
\hline $\begin{array}{c}\text { タンダステンカーバイド } \\
\text { 溶射 } \\
\end{array}$ & 1 & 大 & 6 & 6 \\
\hline $\begin{array}{c}\text { アルミ十焼結材 } \\
\text { (比較用) }\end{array}$ & 4 & 中 & 1 & 2 \\
\hline $\mathrm{Ni}$ 一W めっき & 8 & 中 & 8 & 8 \\
\hline Crめっき & 3 & 大 & 6 & 7 \\
\hline $\mathrm{SiC}$ 分散 $\mathrm{Ni}-\mathrm{P}$ めっき & 7 & 小 & 2 & 4 \\
\hline
\end{tabular}

〔厚 み測 定〕

各テストピースの厚みをマイクロメーターで1点に つき三回測定し, その平均値を求めて当該位置におけ る皮膜の残存厚みとした。なお, 測定位置は図8に示 す。

\section{2 得られたデータの評価について}

皮膜の残存厚み測定結果から最小 2 乗法により傾き を求め摩耗減量として評価した。また，フェルトの損 傷についても摩耗試験後（フェルト走行距離䄪 1 万 5 千 km) フェルト外観で評価した。

\section{3 リップ摩耗試験結果}

フェルト走行距離とリップ残存厚みの関係を図9に 示す。また，摩耗試験後の表面外観を図 10 に示す。

最小 2 乘法により傾きを求めた結果やフェルトの外 観，それに摩耗試験後の供試リップ表面（図 10）な どの調査結果を表 5 に取りまとめた（表中の数字とし ては 1 が最も優れていることを示している)。表 5 よ り以下のことが明らかになった。

(1) 皮膜の耐摩耗性としてはタンタステンカーバイ ド溶射及びクレーアルミナ溶射が最も優れている。

2)フェルトの損傷を進行させないという点では $\mathrm{SiC}$ 分散 $\mathrm{Ni}-\mathrm{P}$ 合金めっき, ジルコニア溶射, 酸 化クロム溶射などが優れている。

3 候補皮膜の局部表面傷の程度はアルミ十焼結体 が最も少なく $\mathrm{Ni}$ 一 W めっきが最も多い。

4, 一部例外はあるが, 皮膜の稫摩耗性が高いもの はフェルトの損㩐を進行させやすい。

5) 総合的に評価するとクレーアルミナ溶射, 酸化
クロム溶射及び $\mathrm{SiC}$ 分散 $\mathrm{Ni}-\mathrm{P}$ めっきが優れた 結果を示した。

以上からリップ皮膜の耐摩耗性としてはグレーアル ミナ溶射とタンタススンカーバイド溶射が優れている ことが分ったか，後者はフェルトへの損傷性の問題が ある。一方, 前者のグレーアルミナ溶射は他の皮膜と 比べると厚膜化が可能で局部表面傷についても良好な 特性を示している。従って耐摩耗性を主体とするなら ばリップ皮膜材料として最適と言える。また，フェル トの損傷を進行させないということが第一優先であれ ば酸化クロム溶射が適していると言えよう。

6. 結論

1）新たな角型リップの開発を行なってきた結果， 基板の樹脂材料：特殊フェノール樹脂, 接着郕：エポ キシ系接着剤の組み合わせが最も良好な特性を示し実 用化の目途が立った。

2）リッブ被覆材料としては使用するフェルト側か ら見れば酸化クロムとなり、リップ側に主体を置けば クレーアルミナ溶射が適しているという結果となった。 なお，現在実機で使用されている多種多様のフェルト 及び葢品で試験を行なってはいないが, 本試験で今回 取り上げた樹脂材料, 接着凨, 皮膜でほほ満足できる と考えられる。また，コスト低隇及び製作工法の目途 が立ち，実機卜ライに移行する予定としているので製 紙メーカー殿や製紙機械メーカー各社のご指導とご協 力の程を宜しくお願いしたい。 
機構により優れたろ過と異物除去を連続的に行うことができることである。連続運転のため，逆洗時の バックアップフィルターが不要となったことによりフィルター洗浄の必要がなくなり，それによる下流 浸度変化を極力少なくすることが可能となった。

(本文 32 ページ)

\section{ASA サイズ発現機構について}

星光 PMC 株式会社 研究關発本部 松帛邦彦, 高岡 学, 雑古博文, 坂本有紀，足立普男

ASA は中性抄造に広く使用される合成サイズ剂の一つとして良く知られているが，㻓境問題，古紙 使用比率の增大，抄造系内のクロースド化によるアニオントラッシュと呼ばれるサイス性阻害物賈の增 加及び抄造系の $\mathrm{pH}$ 上界によって益々その重要性は高まってきている。

ASAのサイズ発現機粠に関する報告は数多く出されているが，更なる知見を深めることを目的とし て ASA 及びその加水分解物について検討を行った。検討に除して，最も単純な系で検討を行うために， 実験は嘘秪を用い, ASA 又はASAcid（ASA 加水分解物）の水乳化物及びASA 又は ASAcidのトル エン溶淮による含浸法で行った。

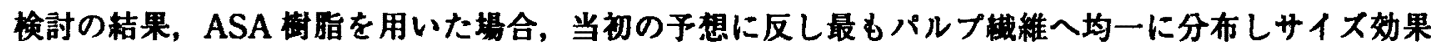
に優れると思われたトルエンワニス含浸よりも，水䄽化物含浸の方が優れたサイズ効果を発現した。 ASA サイズ都を用いたサイジングにおいても他のサイス刜を用いた場合と同様にパルブ臷維上でのサ イス剤分布は重要であるが, 得られた結果から,パルブ織維上にサイズ剂の均一皮膜を形成することは 必ずしも重要ではなく，サイス郕成分をある大きさの点で分布させることの方が，サイズ効果を効事的 に発現させるには重要な要素ではないかと思われた。

(本文 36 ページ)

\section{長寿命溶射リップの開発}

\section{株式会社野村金金 技街部 清水 亮、藤田 得生}

フェルトサクションボックス（別名：エールボックス）は抄紙機のブレスパートに設顝され，真空を 作用させる事で湿紙から䬽水された白水の污れ及びフェルトをクリーニングするシャワー水除去等の役 目がある。当社では'97 年に溚射丸形リッブを開発したが, サクションリップ長寿命化, コスト低下, 軽量化等を目的とし角型リップの開発を再スタートした。リップの棓造は表面処理を施したステンレス の板と樹脂の基板とを接着した梅造とした。基碳試験を行なった結果，椡脂材料は特殊フェノール樹脂 及びFRP，接着剤はエボキシ系を用いることとした。また，リッブ皮膜はテーバー糜耗試験の結果を 参考にし, タンクスステンーパイド溶射, 睌化クロム溶射, クレーアルミナ溶射, ジルコニア溶射, $\mathrm{SiC}$ 分散 $\mathrm{Ni}-\mathrm{P}$ めっき, $\mathrm{Ni}-\mathrm{W}$ めっ $\mathrm{Cr}$ めっき,アルミナ烧結材の 8 種類について検討した。搌似リッフ

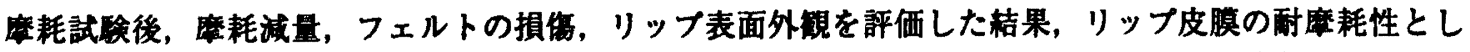
てはクレーアルミナ溶射とタンクステンカーパイド溶射が侵れていることが分ったが，後者はフェルト への損侮性の問题がある。一方, 前者のグレーアルミナ溶射は他の皮膜と比べると厚膜化が可能で局部 表面伤についても良好な特性を示している。従って耐磨耗性を主体とするならばリッフ皮膜材料として 最適と言える。また，フェルトの損侮を進行させないということが第一優先であれば酸化クロム溶射が 暗していると言えよう。

(本文 44 ベージ) 